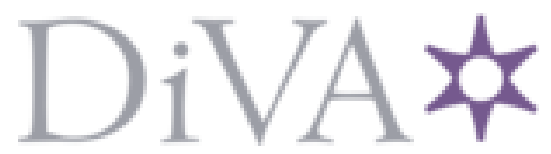

http://www.diva-portal.org

This is the published version of a paper presented at INTED2017 (11th annual Technology, Education and Development Conference), Valencia, Spain, 6th-8th March, 2017.

Citation for the original published paper:

Lagergren, A., Holmberg, K. (2017)

Learning "Theory and Methodology of Science" in Professional Education - A Case Study.

In: L. Gómez Chova, A. López Martínez \& I. Candel Torres (ed.), INTED2017 Proceedings:

11th International Technology, Education and Development Conference: March 6th-8th, 2017

- Valencia, Spain: Conference Proceedings (pp. 6924-6929). IATED

https://doi.org/10.21125/inted.2017.1605

N.B. When citing this work, cite the original published paper.

Permanent link to this version:

http://urn.kb.se/resolve?urn=urn:nbn:se:hh:diva-34074 


\title{
LEARNING "THEORY AND METHODOLOGY OF SCIENCE" IN PROFESSIONAL EDUCATION - A CASE STUDY
}

\author{
Anniqa Lagergren, Kristina Holmberg \\ Halmstad University (SWEDEN)
}

\begin{abstract}
The aim of the project is to study students' learning in a transformed course in Theory and Methodology of Science (TMS), a compulsory course in all teacher education programs in Sweden.

The students perceive the course TMS as difficult and abstract. At the same time it offers an important foundation for their continued education such as their final thesis and other research-related courses. Hereby it's important for students to successfully pass, not only for the course itself, but also for subsequent courses. In a wider perspective, it is also sigificant for the development of the educational field, and to the students' future workplaces. Our students should be able to understand and apply research for years to come. Heavy courses can also be problematic for economic reasons. Since few students are passing, they do not generate as much money as courses that many students pass. There are also examples where teachers are asked by the management to lower the requirements to increase the pass rate.
\end{abstract}

As teachers we have put a lot of effort into the course to support and help students learning. Despite this, only $35 \%$ passed the exam in spring 2016 , which gave rise to the learning experiment we designed and studied this fall. The pedagogical idea is based on a problem-oriented learning, participatory learning and self-organized learning. This means that the students themselves are largely responsible for the organization of their learning. Teachers work with lectures and seminars, as well as coaching and scaffolding. The course is designed as an authentic empirical research project where both quantitative and qualitative data is used as a starting point. Students work in teams. They organize their work in the project by them selves and write a common research rapport. Through the reformed course, learning is combined with a great student responsibility, where students meaning making, socialization and co-learning are central. Hence, the most important research group work takes place is the project-office-rooms where the students' main course work is performed. The organization of the course involves that students themselves designates project managers and that they take responsibility for their joint work, week by week. They can also request extra support from the teachers, if necessary.

The result of the study shows that $86 \%$ of the students received a passing grade. The aspects that matter most to the success are: 1) common spaces, the project office, which creates opportunities to exchange knowledge and experience IRL, 2) problem-oriented learning, participatory learning and self-organized learning, increasing participation and motivation, 3) Collective responsibility for knowledge formation during the project period, and 4) Authentic approach of the course, which by its design as closely as possible should simulate real research projects.

Keywords: professional education, teacher education, course design, participatory learning, problemoriented learning, self-organized learning, democracy.

\section{INTRODUCTION}

In today's knowledge-based economy, it is essential that the skills of all people become utilized in the educational system. The demand for higher competences in society will not diminish but rather continue to grow rapidly ${ }^{1}$. This means that customized learning systems have transformed from being a model distinguishing talented students, to create opportunities and development of all students. According to OECD, this is the only way for a society to be transformed into a knowledge society. Hereby requirements of teachers' competences and professional knowledge will be changed, and teachers' professional work will enter a new paradigm.

At the latest reformation of the Swedish teacher education in 2011, theory of science and critical perspectives were identified as areas of particularly essential significance ${ }^{2}$. It is emphasized that teacher education should not only be a professional training but also an academic education. The report also stresses that this knowledge content should impregnate the entire teacher education and 
not only a few separate courses. Also, Wahlström and Alvunger ${ }^{3}$ highlight the importance of theory of science in teacher training and that this knowledge content should be in line with the latest research findings. Three criteria are presented: 1) research based course literature, 2) teaching is driven by research and research skilled teachers, and 3) that the training is characterized by open and critical discussions where argument are considered and reflected related to each other. Also, a research based teacher education means that students will develop knowledge according to theory and methodology of science, and then be able to implement relevant and current research in their future profession. Whalström and Alvunger point out two areas deficient in the implementation of theory of science in today's teacher education. First, they highlight a deficit of critical conversations where arguments are examined and considered against each other. Second, they point at a lack of skilled research active teachers in teacher education.

Quality in teaching is central to student learning. An attempt to define quality should be based on the parameters that have the greatest impact on student learning and to what extent students reach the learning objectives. Usually teachers' skills are measured as teacher experience, as academic ability, and as subject-matter knowledge ${ }^{4}$. But, also other abilities are important, but much more difficult to measure. These include: the ability to convey ideas in a clear way, creating effective learning environments, promoting good relations between teachers and students, to be enthusiastic and creative, and finally, to work effectively with colleagues.

Quality of teaching is also about creating sustainability and an increased attractiveness of the teacher profession. Some possibilities here are the dissolution of the traditional view of the teacher-student relation. One teacher per student group are hereby challenged by a strong teacher collaboration and co-teaching ${ }^{5}$.

The course "Theory and Methodology of Science" (TMS) is important according to several studies. Research shows that there are shortcomings in the scientific quality in teacher education. Also, the students perceive the course TMS as difficult and abstract. At the same time it offers an important foundation for their continued studies as their final thesis and other research related courses. Hereby it's important for students to successfully pass, not only for the course itself, but also for subsequent courses. In a wider perspective, it is also significant for the development of the educational field, and to the students' future workplaces. The students should be able to understand and apply research for years to come. Heavy courses can also be problematic for economic reasons. Since few students are passing, they do not generate as much money as courses that many students pass. There are also examples where teachers are asked by the management to lower the requirements to increase the pass rate. As teachers we have put a lot of effort into the course to support and help students learning. Despite this, only $35 \%$ passed the exam in spring 2016 , which gave rise to the learning experiment we designed and studied this fall.

Overall, there are high expectations on the students to achieve good results in TMS. There are also hopes on teachers' ingenuity when it comes to ideas about teaching and course designs. The knowledge content is presented as important for student continuing education and their future profession. If they as students become familiar with research within their teacher training program, it could be expected that they will continue to keep themselves informed with respect to current and relevant research in their future profession. In a more general perspective and in the light of the building of a knowledge society, it is important for students to pass their courses. This is also about social sustainability.

This project is expected to contribute to increased quality in terms of students' knowledge, and hereby also to an increased goal achievement. The aim of this paper is to discuss a course design in a reformed course in "Theory and Methodology of Science".

\section{PEDAGOGY}

The approach is problem-oriented learning ${ }^{6}$ participatory learning ${ }^{7}$ and self-organized learning ${ }^{8}$. This means that the students themselves are responsible for the organisation of their knowledge formation and that the teachers besides being lecturers, leaders of seminars, responsible for examinations and so on, also take the role as coach and supporters of student projects. Problem oriented learning in the course TMS is that scientific problems and tasks are the grounds for learning. In this case the problem is; the implementation of an empirical study based on scientifically based choices of research problems. The research problem therefor becomes the heart in the course that students and teachers work with and solve together. The course is designed around each research problem within the 
educational field of research connected to the teacher profession including empirical production of both quantitative and qualitative data.

Based on research that demonstrates a connection between academic achievement and student's engagement ${ }^{9}$, teachers in higher education are encouraged to work with student engagement in different ways. Advantages of such approach are that students can get a deeper understanding of their own learning, a stronger engagement, motivation and enthusiasm ${ }^{10}$.

Further advantages is students possibilities to achieve metacognitive awareness and furthermore a stronger feeling of identity ${ }^{10}$. Finally, through student's participation and engagement teachers get help to identify different areas that need to be developed in the teacher-training programme ${ }^{10}$. Problems with student engagement in form of participation and influence may involve that students are unaccustomed to such working method ${ }^{11}$. The reason for this may be that students in their earlier education not have had the possibility to be part of or have any influence in their educational work or studies.

There are many different perceptions of student engagement. One perception includes student engagement out of behavioural, emotional and cognitive aspects. This includes student's participation in a social context. Furthermore, an emotional involvement in learning, motivation and self regulated learning ${ }^{12}$. Another perception of student engagement comprises the pedagogical purpose that would be to optimize student's experiences, development and improving their achievements ${ }^{13}$. Finally, student engagement is discussed in relation to student-teacher partnership, active student participation, and students as agents of change of content and form in the educational design ${ }^{9,10,11}$.

In this paper student engagement is used in form of participation and influence as a departure for inviting the students in designing the course. In the long run this approach is seen as a way to promote democratic values in higher education ${ }^{14}$.

With problem-oriented learning and student's engagement in mind, self-organized learning becomes another important pedagogical idea in the course. The term and the idea of self-organized learning is borrowed from studies of children's self-organized learning in relation to digital technology ${ }^{8}$. The key to get the learners, in this case the students, to organize their own learning is related to what kind of study environment that is afforded. In the course, scientific theory and method such an environment is offered. In order to support social interaction between students and students and teachers, they are scheduled to attend from eight pm until five am each day. Also, the spatial context is of importance to support self-organize learning. Therefore, the students have access to shared meeting places not only in teaching activities but places that affords students to interact with each other closely.

\section{COURSE DESIGN}

The course in TMS is performed during five weeks. Each week contains one of five themes.

The first week is dedicated to the theme philosophical paradigms, week two of the research problem, the third week of methodology of science, the fourth week of analysis and the fifth week compilation and academic writing of a scientific report.

Week 1: Week one in the course starts with the students divides themselves in research groups of four students and research teams of eight students. The students start working in the research team with studies of philosophical paradigms and with assignments that links the students together in scientific discussions in order to comprehend what the different philosophical paradigms stands for. The weed ends with a quiz where the research teams create one question for each paradigm. Then, all students answer the quiz individually. In conclusion all students are gathered to discuss the answers and conclude the theme of the week.

Week 2: Theme two in the second week is dedicated to formulate a relevant research problem with a suitable purpose and research questions that are inline with the philosophical paradigms they think they will use. This theme also consists of an assignment that is compulsory, that is to perform a survey. The survey is connected to the national curriculum of teacher education in Sweden, in order to achieve knowledge of quantitative data.

Week 3: Week three is dedicated towards continuous work designing their research methods such as interviews, observations and the required survey and then collection of empirical data. 
Week 4: Weed four focuses on analysis. The student's processes and analyses their collected material with teacher support in form of workshops aimed towards different kinds of quantitative and qualitative analyse methods.

Week 5: The last week in the course, the student's work with their research reports that also is the examination task of the course.

\section{RESULTS}

Here are the results of the study.

\subsection{Participatory learning}

Participatory learning is evident in the course and is made possible because of the teacher's flexibility. The course has a clear structure however, is not strict. The flexibility makes it possible for students and teacher to be in a learning process together. It is possible to adjust and adapt different course activities in relation to what the students and teacher find necessary. This is possible, since we are several teachers and we have the time.

Us teachers experience that we are working with the students in their learning processes out of the student's needs and initiative. We observed that students engagement for the scientific problem and the main learning goals in the course are strong. The students took initiative to interactions between one another and towards the teachers. At the same time the students now and then expresses desires to get the "right answers" from us teachers, which is problematic. This testifies, that students have earlier experiences from their education where the critical dialogue is absent. Thus, the students are not used to participate in this form of dialogue that creates a felling of uncertainty and stress. However, student's commitment also creates a significant factor of power in relation to the teachers. The consequence of this is that student's express greater demands on us teachers and other students.

\section{Example 1}

One example of this from the course, is from students participation in the critical dialogue. In a workshop the students write their purposes and research question on the white board. Their formulations are then used as a departure for a critical discussion including both active students and teachers. All participants contribute to the discussion with their knowledge in the discussion. Nothing is right or wrong, instead thoughts and ideas from each group are visible making the base for a critical dialogue.

\section{Example 2}

Another example of this is when the students are involved in a critical dialogue during a quiz. The students creates questions based on affordances from literature, lectures and discussions the have participated in during the first week. Us teachers do not examine or stop any questions before the quiz. Instead the critical dialogue is used to discuss the questions after the quiz. In that critical dialogue different interpretations of concepts and terms become visible and students and teachers discuss the questions relevance and problems in relation to the knowledge area that in this case is scientific paradigms.

\subsection{Problem-oriented learning}

Another aspect related to the examples presented above, is about problem-oriented learning. Traditionally designed courses in TMS are, according to our experience, more instrumental and predetermined. Often the courses are examined with fixed questions and answers. Our course is instead based on students' freedom to choose problems to investigate, and freedom to choose methods and theories. They also have to develop arguments related to their choices, to be able to stand up for what they have decided. As part of the course design, there are many different solutions and problems that the students have to handle, and discuss.

Central is to make the students decide by themselves which road they should walk, and how they should investigate their problems. This also means that students sometimes get frustrated. Metaphorically, one could say that they cannot slip up on one of the teachers predetermined and structured way of relevant knowledge. Thus, there is no highway, but it is a bumpy gravel road that that students must walk on. Sometimes they might even themselves have to disclose a feasible path. 


\subsection{Self-organized learning}

Another aspect we have observed in the course is about self-organized learning. In this form of learning in the course, students themselves organize their work. For example, it means that the students themselves structure their work, they distribute work, they decide how they continually should solve problems that occur and which knowledge sources they should use. This is also about making choices in relation to theory and methodology of science in the research they are involved in. The selforganized learning is also about places and social constellations. For example, the students are moving between different environments and select rooms and locations as needed. They organize themselves socially in different ways, within the group and in relation to other groups of students. They support each other and explain to each other. It can be about concepts, methods, theories and other things. This suggests that the students have good knowledge of each other's competencies and thus can take the help of each other. An event where this is expressed is when a group of student did not understand the teacher's explanations. Then they went to another student group for further elucidations. This was fortunate as the students then became able to understand the problems they had to deal with. There are also instances when the self-organized learning does not work. As teachers we noticed that students in one group were not present on several occasions when they were supposed to work. Afterwards, these students reported that they had a joint document that they worked with over the Internet. However, they had not planned nor organized their work so that the common text was messy and unsatisfactory. According to their own accounts, they also had cooperation problems because they were four strong individuals who wanted different things and therefore could not agree.

\subsection{Grades}

How students meet the goals in a course can be measured through grades. In this course, students that used the common spaces which the course had available gained a pass grade for the course. However, the students that decided not to use the common spaces the course had available, did chose to work in other spaces on their own, did not did not gain a pass grade for the course. These students could not participate in dialogues about the content in the course. The same students told us teacher later on that, their group was dysfunctional; they have had problems working together.

\section{DISCUSSION}

In the following section the discussion is divided into three headlines of democratic values, the critical dialog and the cultural space. The reason for the discussion is to open up a pedagogical discussion in how to move further in the project.

Democratic values. In an overall perspective participatory learning, problem-oriented learning and selforganized learning creates teaching that supports and makes it possible for students influence in several levels and areas. The course assignment is to plan, perform and report a scientific project within one of the three research areas that the teachers are active in. The students are in that way limited while us teachers can guarantee a good teacher- research competence in relation to all of research projects that the students choose to perform. Despite this, the students experience that they have influence in what direction to choose in their projects.

Another democratic aspect is that the students are expected to be capable in taking responsible for their own learning during the course. The teachers have chosen the literature and continuously through out the course recommends research of relevance and through out the course takes responsibility overall for the course. Content and approach for the scientific project is the student's responsibility.

The critical dialogue. The critical dialogue is of great importance for the development of the teacher profession and the academic performance of the teacher-training programme. That teachers and students together reflect and discuss different perspectives and possibilities in an open dialogue is one example of this. To be part of a researching environment where everybody is doing research with no limits or decisions made in research objects demands dialogue and discussion. At the same time may, such an approach create frustration within the student group. The reason for this may be that they are unaccustomed to meet "the unfinished" and the "non-instrumental".

The cultural space. Both culture and space as a frame in the course means that the students are "stepping in" to a context where the position as a researcher is present to a large extent. The students are invited into our research areas and to participate in the debates that are on going in the field. This 
frame creates authenticity and nerve in the students own research projects. It is for real! They are getting closer to the basic ideas and get an opportunity to toss and turn their aims and research questions. Opportunities for discussions of their different ontological and epistemological positions and what implications they will have for their project. They are given the opportunity to reflect on knowledge, and different ways to study the reality questions that all researchers are struggling with. The students are thinking together and discuss together and all these activities gives them access to a researching environment. They are being part of a scientific context.

\section{REFERENCES}

[1] OECD, "Creating Effective Teaching and Learning Environments. First Results from TALIS." 2009.

[2] SOU2008: 109, "En hållbar lärarutbildning" [A sustainable teacher education], 2008.

[3] N. Wahlström and D. Alvunger, "Forskningsbasering av lärarutbildningen" [A research based teacher education], 2015.

[4] OECD, "Teacher Matter. Attracting, developing and retaining effective teachers." 2005.

[5] C. Natale, K. Bassett, L. Gaddis, \& K. MacKnight. "Creating Sustainable Teacher Career Pathways. A 21 Century Imperative. 2013.

[6] M. Elmgren, A-S. Henriksson, "Universitetspedagogik", Stockholm: Norstedts, 2010.

[7] A. Persson, "Studentinflytande i massuniversitetef". Lunds Universitet, 1998.

[8] S. Mitra, \& V. Rana, Children and the Internet: experiments with minimally invasive education in India, British Journal of Educational Technology, vol. 32, no. 2, 2001.

[9] P. Baron, L. Corbin, Student engagement: rhetoric and reality. Higher Education Research \& Development, 31(6), 759-772, 2012.

[10] C. Bovill, A. Cook-Sather, \& P. Felten, Students as co-creators of teaching approaches, course design, and curricula: implications for academic developers. International Journal for Academic Development, 16(2), 133-145, 2011.

[11] C. Bovill, An investigation of co-created curricula within higher education in the UK, Ireland and the USA. Innovations in Education and Teachin International, 51(1), 15-25, 2014.

[12] J. A. Fredericks, P. C. Blumenfeld, A. H. Paris, Shool engagement: Potential of the concept, state of the evidence. Review of Educational Research, 74(1), 59-109, 2004.

[13] V. Trowler, "Student engagement literature review", York, UK: The Higher Education Academy, 2010.

[14] M. Dahlstedt, \& M. Olson, “Utbildning, demokrati, medborgarskap", Malmö: Gleerups, 2013. 